\title{
IDENTIFICATION OF VIRULENCE GENES CARRIED BY BACTERIOPHAGES OBTAINED FROM CLINICALLY ISOLATED METHICILLIN- RESISTANT STAPHYLOCOCCUS AUREUS
}

\author{
DJursun Karasartova, Zeynep Burcin CAVusoglu, Buse Turegun, \\ MURAT T. OZSAN and FIKRET ŞAHIN*
}

Microbiology Department, Faculty of Medicine, Ankara University, Ankara, Turkey

(Received: 15 March 2016; accepted: 23 June 2016)

\begin{abstract}
Bacteriophages play an important role in the pathogenicity of Staphylococcus aureus (S. aureus) either by carrying accessory virulence factors or several superantigens. Despite their importance, there are not many studies showing the actual distribution of the virulence genes carried by the prophages obtained from the clinically isolated Staphylococcus. In this study, we investigated prophages obtained from methicillin-resistant $S$. aureus (MRSA) strains isolated from hospital- and community-associated (HA-CA) infections for the virulence factors. In the study, 43 phages isolated from 48 MRSA were investigated for carrying toxin genes including the sak, eta, lukF-PV, sea, selp, sek, seg, seq chp, and scn virulence genes using polymerase chain reaction (PCR) and Southern blot. Restriction fragment length polymorphism was used to analyze phage genomes to investigate the relationship between the phage profiles and the toxin genes' presence. MRSA strains isolated from HA infections tended to have higher prophage presence than the MRSA strains obtained from the CA infections ( $97 \%$ and $67 \%$, respectively). The study showed that all the phages with the exception of one phage contained one or more virulence genes in their genomes with different combinations. The most common toxin genes found were sea $(83 \%)$ followed by sek $(77 \%)$ and seq $(64 \%)$. The study indicates that prophages encode a significant proportion of MRSA virulence factors.
\end{abstract}

Keywords: S. aureus, bacteriophages, virulence genes

\section{Introduction}

Staphylococcus aureus (S. aureus) is responsible for many hospital- and community-associated (HA-CA) infections [1]. Methicillin-resistant S. aureus

*Corresponding author; E-mail: fsahin29@hotmail.com 
(MRSA) appeared in 1960 and became an important healthcare problem over the following years [1-3]. It is virulent and resistant to antimicrobials [4]. S. aureus can produce more than 30 different extracellular proteins [1]. Most of them have been described and characterized, such as the staphylokinase (SAK), the chemotaxis inhibitory protein (CHIP), the staphylococcal inhibitor of complement (SCIN), and several superantigens including SEA, SEG, SEK, SEP, and SEQ [5, 6]. These superantigens are enterotoxin. They may cause food poisoning, toxic shock syndrome, and necrotizing fasciitis. Panton-Valentine leukocidin (PVL, encoded by $l u k F-P V, l u k S-P V)$ is cytotoxin. PVL creates pores into leukocytes and cause necrotic infections. The exfoliative toxin A (ETA) is involved in severe skin infections [7].

The staphylococcal virulence factors are mostly encoded by genetic elements such as prophages, transposons, plasmids, and pathogenicity islands [8]. Most likely due to horizontal transfer, these mobile elements are not found equally among clinical isolates, and there are significant variations between different strains $[8,9]$.

The vast majority of bacteria contain prophages, which cause substantial genetic variability. It is known that they constitute major vehicles for horizontal gene transfer $[5,10]$.

During the past decade, sequencing of Staphylococci genomes and improvements in the comparative genomic analyses has significantly increased the number of staphylococcal phages identified. To date, more than 68 Staphylococci phages and prophages' sequences, mainly from $S$. aureus, are identified [5].

All $S$. aureus genomes sequenced so far do contain at least one prophage, and many strains contain up to four [5]. These encode numerous staphylococcal toxins responsible for pathogenesis $[8,9]$. Despite their importance, there are not many studies showing the actual distribution of the toxin genes carried by the prophages obtained from the clinically isolated Staphylococcus. A comprehensive picture of the distribution of virulence factors carried by the prophages in the S. aureus strain populations was lacking. A study showed that the MRSA isolates harbored more superantigenic toxin genes than the MSSA isolates [11]. In this study, 43 phages isolated from 48 MRSA were investigated for carrying toxin genes including the sak, eta, lukF-PV, sea, selp, sek, seg, seq chp, and scn toxin genes. We also analyzed the phages using restriction fragment length polymorphism (RFLP) and investigated the relationship between the phage profiles and the toxin genes' presence. Although our approach does not allow drawing exact conclusions whether the found virulence genes are present on a single phage or are distributed on different phages, the analyses showed that $95 \%$ of all phages contain one or more toxin genes in their genomes with different combinations. 


\section{Materials and Methods}

\section{Study strains}

Forty-eight $S$. aureus strains isolated from hospitalized patients, and outpatients of different clinics of the Haydarpasa Numune Teaching and Research Hospital, Istanbul, Turkey, in 2004 and 2005, were included in the study (Table I). The isolates were identified as $S$. aureus by conventional methods (Gram stain morphology, catalase and DNase production) and were confirmed by the production of clumping factor and polyclonal IgG antibodies against protein A and capsular polysaccharide (Staphytect test; Oxoid Ltd., Basingstoke, Hampshire, England). Methicillin resistance was detected with the $m e c A$ gene with PCR and confirmed with the conventional method, the oxacillin disk diffusion test [12]. S. aureus ATCC 25923 and S. aureus ATCC 700699

Table I. MRSA isolated from samples, clinics, and presence of phage

\begin{tabular}{|c|c|c|c|}
\hline Samples & Clinics & MRSA & Prophage \\
\hline $\begin{array}{l}\text { Tracheal } \\
\text { aspirates }\end{array}$ & Reanimation & $\begin{array}{l}\text { H412, H385, H413, H459, } \\
\text { H350, H143 }\end{array}$ & + \\
\hline $\begin{array}{l}\text { Tracheal } \\
\text { aspirates }\end{array}$ & Reanimation-2 & $\begin{array}{l}\text { H1057, H1003, H971, } \\
\text { H895 }\end{array}$ & + \\
\hline Catheter samples & Reanimation-2 & H410, H807 & + \\
\hline Blood culture & Reanimation & Н328, Н391 & + \\
\hline $\begin{array}{l}\text { Tracheal } \\
\text { aspirates }\end{array}$ & Neurosurgery & $\begin{array}{l}\text { H318, Н370, Н345, Н389, } \\
\text { H477, Н1046 }\end{array}$ & + \\
\hline CSF & Neurosurgery & H487, Н376 & + \\
\hline Catheter samples & Neurosurgery & H479, Н378, H201 & + \\
\hline Pus & Surgery & H31 & + \\
\hline Peritoneal fluid & General surgery-2 & Н302, H481 & + \\
\hline Blood culture & General surgery-4 & $\mathrm{H} 715$ & + \\
\hline Blood culture & Dialysis unit & $\mathrm{H} 421$ & + \\
\hline Blood culture & Neurology & $\mathrm{H} 435$ & + \\
\hline Blood culture & Medicine & H475, H464 & + \\
\hline Sputum & Medicine & $\mathrm{H} 3$ & + \\
\hline Ear secretion & ENT surgery & H368 & + \\
\hline Urine samples & Outpatient - obstetrics and gynecology & $\mathrm{C} 3, \mathrm{C} 90, \mathrm{C} 52$ & + \\
\hline Nose secretion & Dermatology & $\mathrm{C} 33$ & + \\
\hline Urine samples & Outpatient - urology & C9, C54, C66 & + \\
\hline Joint fluid & Outpatient - orthopedic & $\mathrm{C} 46$ & + \\
\hline Joint fluid & Outpatient - orthopedic & $\mathrm{C} 24$ & - \\
\hline Urine samples & Outpatient - urology & C71 & - \\
\hline Ureter secretion & Outpatient - urology & $\mathrm{C} 17$ & - \\
\hline Urine samples & Outpatient - urology & C64 & - \\
\hline Blood culture & Reanimation & H623 & - \\
\hline
\end{tabular}


(Mu50) strains were used as methicillin-susceptible and methicillin-resistant standard controls, respectively.

\section{Isolation of phage particles}

The method of Kaneko et al. [13] was used with some modifications. Briefly, after cultivating bacteria in heart infusion broth on a shaker at $37^{\circ} \mathrm{C}$ for $3 \mathrm{~h}$, mitomycin $\mathrm{C}(\mathrm{MMC})$ was added at a final concentration of $1 \mu \mathrm{g} / \mathrm{mL}$ of the mid-exponential phase and cultivation was continued for $5 \mathrm{~h}$. Bacteria were centrifuged at $10,000 \times g$ for $15 \mathrm{~min}$, and the supernatant was filtered twice through a $0.2-\mu \mathrm{m}$ filter. The phage-containing supernatant was treated with DNase I and RNase A ( $1 \mu \mathrm{g} / \mathrm{mL}$; Sigma-Aldrich Corp., St. Louis, MO) at room temperature for $1 \mathrm{~h}$, and then polyethylene glycol 6000 at a final concentration of $10 \%(\mathrm{w} / \mathrm{v})$ was added. After incubation for $12 \mathrm{~h}$ at $4{ }^{\circ} \mathrm{C}$, phage particles were recovered by centrifugation at $11,000 \times g$ for $10 \mathrm{~min}$ and suspended in $1 \mathrm{~mL}$ TE buffer and used for preparing the phage genomic DNA.

\section{Phage DNA extraction}

Enzymatic digestion by proteinase $\mathrm{K}(100 \mu \mathrm{g} / \mathrm{mL})$ was performed for $5 \mathrm{~h}\left(55^{\circ} \mathrm{C}\right)$ in $1 \mathrm{~mL}$ of lysis buffer $(0.1 \mathrm{~mol} / \mathrm{L} \mathrm{NaCl} ; 0.21 \mathrm{~mol} / \mathrm{L}$ Tris $-\mathrm{HCl}$; $0.05 \mathrm{~mol} / \mathrm{L}$ ethylenediaminetetraacetic acid, $\mathrm{pH} 8 ; 0.5 \%$ sodium dodecyl sulfate). DNA extraction was then carried out using a phenol-chloroform $(1 / 2 ; 1 / 2)$ extraction [14]. The DNA was then precipitated with absolute ethanol (two volumes) and resuspended in $100 \mu \mathrm{L}$ of $\mathrm{ddH}_{2} \mathrm{O}$ [14].

Screening and analysis of toxin genomes with PCR

The designed sequences of the primers and the expected size of the PCR products are shown in Table II. Table II also shows GenBank accession number of the individual toxin gene sequences in which primers were chosen. PCR amplification was performed in a total of $50 \mu \mathrm{L}$ containing $10 \mathrm{ng}$ of the DNA template, $20 \mathrm{pmol}$ of each primer, $2.5 \mathrm{mmol} / \mathrm{L}$ of the four deoxynucleotides, and $2.5 \mathrm{U}$ of Taq polymerase (Fermentas, Lithuania). The reaction mixtures were subjected to 38 cycles of amplification in GeneAmp 2400 (PE Applied Biosystems, Foster City, CA). After amplification, the PCR products were analyzed by ethidium bromide (EtBr)-treated agarose gel electrophoresis. 
Table II. The name of the virulence genes, designed sequences of the primers, the expected size of the PCR products, and GenBank accession number of the individual toxin gene sequences

\begin{tabular}{|c|c|c|c|}
\hline $\begin{array}{l}\text { Virulence } \\
\text { gene }\end{array}$ & Primer sequence & $\begin{array}{l}\text { Size of the PCR } \\
\text { product }(\mathrm{bp})\end{array}$ & $\begin{array}{c}\text { GenBank } \\
\text { accession number }\end{array}$ \\
\hline SAK & $\begin{array}{l}5^{\prime} \text { TGTGACTGGAGTTGATGGTAC } 3^{\prime} \\
5^{\prime} \text { TGCCATCTAATGCCCATTCGAC } 3^{\prime}\end{array}$ & 140 & KC342645 \\
\hline PVL & 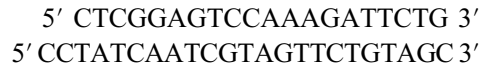 & 245 & AB218700.1 \\
\hline ETA & $\begin{array}{l}\text { 5' GTTATTCAAGACGAACTGATG 3' } \\
5^{\prime} \text { TAACACACCAGTTGCACTTG 3' }\end{array}$ & 230 & AP001553 \\
\hline SCIN & $\begin{array}{l}5^{\prime} \text { AGCACAAGCTTGCCAACATCG 3' } \\
5^{\prime} \text { TTAATATTTACTTTTTAGTGC 3' }\end{array}$ & 225 & СР005288 \\
\hline CHIPS & $\begin{array}{r}5^{\prime} \text { TCAGCAAGTGGTGTATTCAG } 3^{\prime} \\
5^{\prime} \text { ACACACCATCATTCAGCGAAAG } 3^{\prime}\end{array}$ & 250 & EF462199 \\
\hline SEA & $\begin{array}{l}\text { 5' GCATGTATGGTGGTGTAACG 3' } \\
5^{\prime} \text { TGAATTCTGTCCTTGAGCAC 3' }\end{array}$ & 292 & GQ859135 \\
\hline $\begin{array}{l}\text { SEIP } \\
\text { (SEP) }\end{array}$ & $\begin{array}{l}5^{\prime} \text { TTATGGTTATCAATGTACTG 3' } \\
5^{\prime} \text { AATCATAACCAACCGAATCA 3' }\end{array}$ & 300 & EF534985 \\
\hline SEK & $\begin{array}{l}\text { 5' CTCCTATAGCTAATCAACTAC } 3^{\prime} \\
5^{\prime} \text { TGTATTCTTCTTGAAGGTAC 3' }\end{array}$ & 315 & СР003166 \\
\hline SEG & 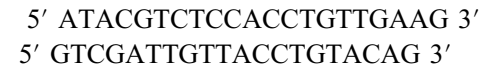 & 295 & СР006044 \\
\hline SEQ & $\begin{array}{l}5^{\prime} \text { CTGATATCCATATTCCTGAC 3' } \\
5^{\prime} \text { TCTACTTCTCATCAATTAGAG 3' }\end{array}$ & 335 & GU723683 \\
\hline
\end{tabular}

\section{Cloning and sequencing of $P C R$ products}

The PCR products were cloned into a pGEM-T vector (Promega, Madison, WI, USA) according to the manufacturer's instructions. The recombinant plasmids were transfected into Escherichia coli DH5 $\alpha$, and the resulting recombinants were screened by the colony PCR method with the vector and insert DNA primers. Nucleotide sequencing of the insert DNA was performed by BigDye Terminator (PE Applied Biosystems, Foster City, CA, USA) sequencing chemistry on an automatic DNA sequencer (ABI 377; Applied Biosystems, Foster City, CA, USA). Sequences obtained were subjected to a BLAST search with registered sequences in the GenBank database for the confirmation of the PCR product.

\section{Southern blot}

The toxin genes' positive and one or more toxin genes' negative phage genomes were cut with HinfI enzyme and run on agarose gel. After transferring to the PVDF blotting membrane, Southern blot was completed with hybridization of biotin-labeled toxin primer probes. The gene primers were labeled with 
biotinylated dNTPs according to the manufacturer's protocol (North2South Biotin Random Prime DNA Labeling Kit; Pierce Biotechnology, Rockford, IL) and used as probes. The hybridization and detection were done by following the protocol of the North2South Chemiluminescent Hybridization and Detection Kit (Pierce Biotechnology), which uses a streptavidin-horseradish peroxidase coupled antibody for detection.

\section{RFLP analysis of phage DNAs}

Phage DNAs were cut with HinfI restriction enzyme and run through an EtBr-treated gel and were visualized and photographed.

\section{Results}

Isolation of phage particles

Forty-eight MRSA strains were examined for prophages. Bacterial cells in the logarithmic phase of growth were treated with MMC. For the prevention of possible bacterial DNA and RNA contamination, the phage-containing supernatant was treated with DNase and RNase. DNAs were extracted and run on agarose gel. It was found that 43 of the 48 MRSA strains contain phagerelated DNA (Table I). No phage was obtained from the five MRSA isolates. One out of thirty-six MRSAs isolated from the HA infections contain phages and four out of twelve MRSAs isolated from the CA infections contain phages (Table I).

\section{Detection of the toxin genes from phage genome}

The existence of the toxin genes in the phage genomes was examined by the PCR method. Figure 1A shows the PCR results of the SCN toxin gene as a representative of the PCR results. Subsequently, the PCR products of each of individual genes were cloned into the pGEM-T vector and were sequenced. The sequences were compared with other DNA sequences in the GenBank database, using a BLAST search. Because of the possibility of the bacterial nucleic acids contamination, the Southern blot was performed for all the PCR positive phages. The toxin genes' positive and one or more toxin genes' negative phage genomes were cut with HinfI enzyme and run on agarose gel. After transferring to the PVDF blotting membrane, Southern blot was completed with 
(A)

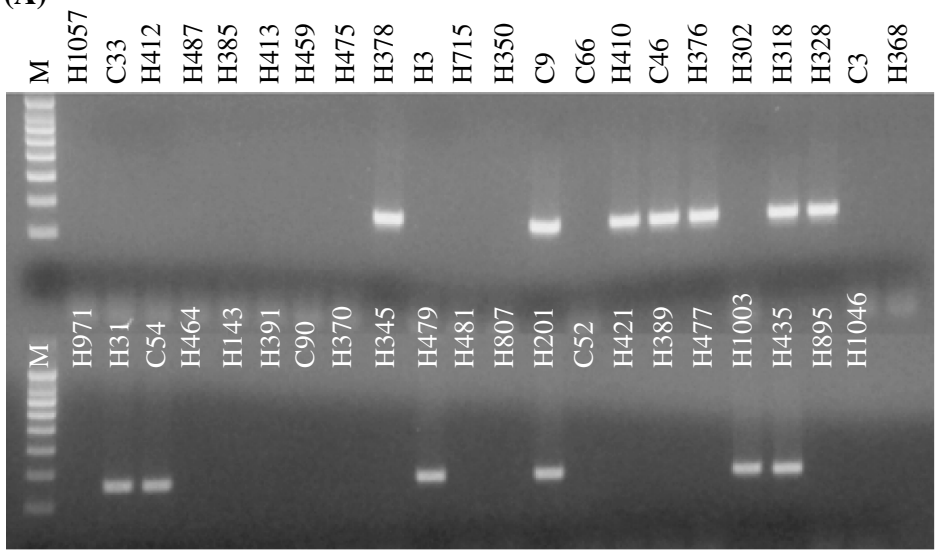

(B)

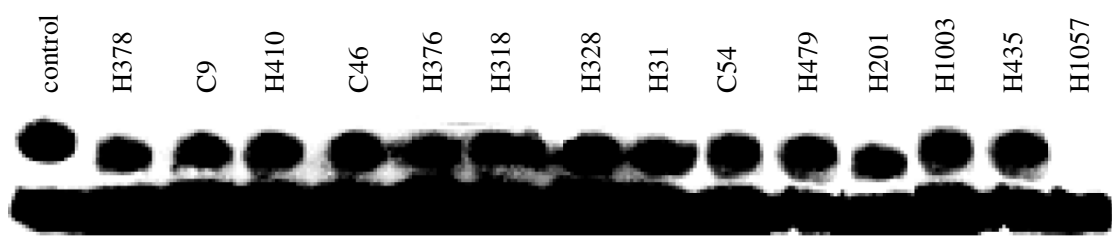

Figure 1. (A) The PCR results of SCIN toxin gene using template DNAs obtained from the phages. (B) Southern blot results using SCN primers labeled with biotinylated dNTPs. All the SCN toxin genes' positive with PCR and H1057 as negative phage genome were analyzed. The PCR product of $\mathrm{SCN}$ was used as positive control. $\mathrm{H}$ and $\mathrm{C}$ correspond to hospital- and community-associated infections, respectively. $\mathrm{M}$ corresponds to $1 \mathrm{~kb}$ DNA ladder

the hybridization of biotin-labeled toxin primer probes. Figure 1B shows the results of the Southern blot of the SCN toxin gene as a representative of the Southern blot results. With the exception of one phage in which MRSA was isolated from the CA infection, all the phages contained toxin genes in their genome (Table III). Two phages contained one toxin gene, and the rest of the phages contained two or more toxin genes in their genomes. In one of the phages, six of the ten different toxin genes searched in this study were found. The most common toxin genes found in the phages were sea $83 \%$, followed by sek (77\%), and seq (64\%). LukF-PV and selp were not found in the 43 phages. It is found that only 1 of the 43 phages carries eta gene (Table III). 
Table III. Bacteriophages were grouped according to the RFLP analysis and the virulence genes carried by the individual phage were shown

\begin{tabular}{|c|c|c|c|c|c|c|c|c|c|c|c|}
\hline \multirow{2}{*}{$\begin{array}{l}\text { Phage } \\
\text { group } \\
\text { no. }\end{array}$} & \multirow{2}{*}{$\begin{array}{c}\text { MRSA } \\
\text { with } \\
\text { phage }\end{array}$} & \multicolumn{10}{|c|}{ Virulence genes } \\
\hline & & SAK & ETA & PVL & SEA & SEIP & SEK & SEG & SEQ & CHIP & $\mathrm{SCN}$ \\
\hline 1 & H1057 & + & - & - & + & - & + & - & + & - & - \\
\hline \multirow[t]{2}{*}{2} & C33 & + & - & - & - & - & - & - & - & + & - \\
\hline & $\mathrm{H} 302$ & + & - & - & + & - & + & - & + & + & - \\
\hline \multirow[t]{8}{*}{3} & $\mathrm{H} 412$ & - & - & - & + & - & + & - & + & - & - \\
\hline & $\mathrm{H} 413$ & - & - & - & + & - & + & - & + & - & - \\
\hline & $\mathrm{H} 475$ & - & - & - & - & - & + & - & + & - & - \\
\hline & H368 & - & - & - & + & - & + & - & + & + & - \\
\hline & H971 & - & - & - & + & - & + & - & + & + & - \\
\hline & H345 & - & - & - & + & - & + & - & + & + & - \\
\hline & H481 & - & - & - & + & - & + & - & + & - & - \\
\hline & H391 & - & - & - & + & - & + & - & + & + & - \\
\hline 4 & $\mathrm{H} 487$ & + & - & - & + & - & + & - & + & - & - \\
\hline \multirow[t]{15}{*}{5} & H385 & - & - & - & + & - & + & - & - & - & - \\
\hline & $\mathrm{H} 459$ & - & - & - & + & - & + & - & + & - & - \\
\hline & H378 & + & - & - & + & - & + & - & + & - & + \\
\hline & $\mathrm{H} 3$ & - & - & - & + & - & + & - & + & - & - \\
\hline & $\mathrm{H} 715$ & + & - & - & + & - & + & - & + & - & - \\
\hline & H376 & + & - & - & + & - & + & - & + & - & + \\
\hline & H318 & + & - & - & + & - & + & - & - & + & + \\
\hline & H143 & + & - & - & + & - & + & - & + & + & - \\
\hline & H370 & - & - & - & + & - & + & & + & - & - \\
\hline & H807 & + & - & - & + & - & + & - & + & + & - \\
\hline & $\mathrm{H} 421$ & - & - & - & + & - & + & - & + & - & - \\
\hline & H477 & + & - & - & + & - & + & - & + & - & - \\
\hline & H1003 & - & - & - & + & - & + & - & - & - & + \\
\hline & H895 & - & - & - & + & - & + & - & - & - & - \\
\hline & H1046 & - & - & - & + & - & + & - & - & - & - \\
\hline 6 & H350 & + & - & - & + & - & + & - & + & - & - \\
\hline 7 & $\mathrm{C} 3$ & + & - & - & + & - & + & - & + & - & - \\
\hline 8 & C9 & + & - & - & + & - & - & - & - & + & + \\
\hline 9 & C66 & - & - & - & + & - & - & - & - & - & - \\
\hline 11 & $\mathrm{H} 410$ & + & - & - & + & - & - & + & - & - & + \\
\hline 12 & C46 & + & - & - & + & - & - & + & - & + & + \\
\hline 13 & H328 & + & - & - & + & - & + & - & + & + & + \\
\hline 14 & H31 & + & - & - & + & - & - & + & - & + & + \\
\hline 15 & C54 & + & - & - & + & - & - & + & - & + & + \\
\hline 16 & H464 & + & - & - & - & - & - & - & - & - & - \\
\hline 18 & C90 & - & - & - & - & - & - & - & - & - & - \\
\hline 19 & H479 & + & - & - & + & - & + & - & + & - & + \\
\hline 20 & H201 & + & - & - & + & - & + & - & + & - & + \\
\hline 21 & C52 & - & - & - & + & - & - & - & - & + & - \\
\hline 22 & H389 & + & - & - & + & - & + & & + & + & - \\
\hline 23 & H435 & + & + & - & - & - & + & + & - & - & + \\
\hline
\end{tabular}




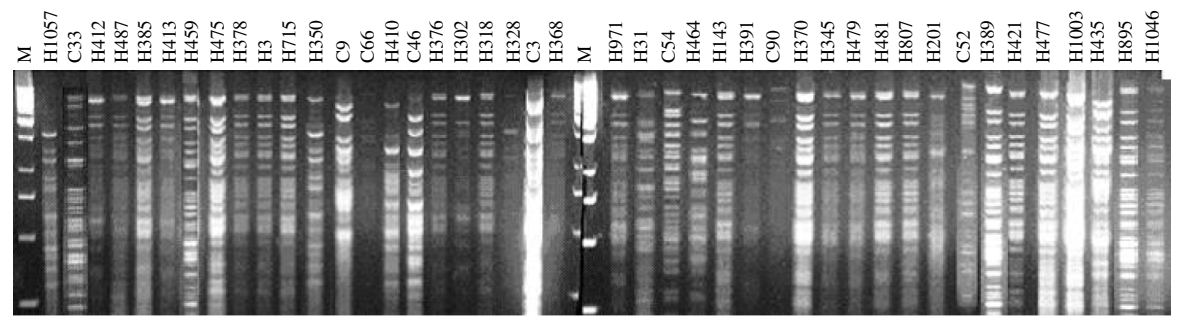

Figure 2. RFLP analyses of bacteriophages' DNAs obtained from MRSA isolates. The phage DNAs were digested with HinfI and analyzed on a $0.9 \%$ agarose gel. M corresponds to lambda/HindIII ladder. $\mathrm{H}$ and $\mathrm{C}$ correspond to hospital- and community-associated infections, respectively

\section{RFLP analysis of phage genomes}

RFLP was used to analyze phage genomes to investigate the relationship between the phage profiles and the toxin genes' presence. Initially, phage genomes were cut with the EcoRI, HindIII, and HinfI restriction enzymes (data not shown). HinfI digestion presented the best discrimination among the DNAs. The RFLP of phage genomes were repeated two or more times. The RFLP analysis of 43 phages displayed 23 profiles (Figure 2 and Table III). Two major groups were obtained: phage groups \#3 and \#5. The group \#5 contained 15 phages according to the visual analysis of phages' RFLP. In the group \#5, all 15 phages contained the sea and sek, 10 of the 15 contained the seq, 7 of the 15 contained the sak, 4 of the 15 contained the $s c n ; 3$ of the 15 contained the $c h p$ toxin genes (Table III). The phage group \#3 contained eight phages. All the eight phages contained the sek and seq, seven of the eight contained the sea, and three of the eight contained the chp toxin genes in their genomes. The other phages contained different combinations of toxin presence (Table III). The RFLP analysis of all the phage genomes showed that the ETA-containing phage and the phage carrying six virulence genes are quite different from the rest of the phage genomes (Figure 2).

\section{Discussion}

The bacteriophages play an important role in the pathogenicity of $S$. aureus either by carrying accessory virulence factors such as PVL, SAK, and ETA or several superantigens [15]. In addition to toxins, phages carry immune evasion clusters (IECs) including SCIN and CHIPS [16]. Despite their importance, a comprehensive picture of the distribution of virulence factors carried by the prophages in the $S$. aureus strain populations was lacking. In this study, we 
investigated prophages obtained from MRSA strains isolated from HA and CA infections for the virulence factors. Interestingly, MRSA strains isolated from HA infections tended to have higher prophage presence than the MRSA strains obtained from the CA infections ( $97 \%$ and $67 \%$, respectively). With the exception of one phage obtained from MRSA which was isolated from the CA infections, all other 42 phages contained one or more virulence genes in their genomes. The most common toxin genes found were the sea (83\%) followed by the sek (77\%) and seq (64\%). SEs are a family of major serological types of heat-stable enterotoxins (SEA through SEE and SEG through SEQ). SEs function both as potent gastrointestinal toxins as well as superantigens that stimulate non-specific T-cell proliferation. SEA was found as the most common toxin especially in staphylococcus-related food poisoning [17].

Although we primarily evaluated the presence of the virulence genes in phages obtained from MRSA, we also analyzed the phages using the RFLP and investigated the relationship between the phage profiles and the toxin genes' presence. Visual analysis of the phages' RFLPs revealed two major groups: phage groups \#3 and \#5. The phage goup \#5 contained 15 phages. All 15 phages carried the sea and sek toxin genes, 10 of the 15 phages carried the seq toxin gene, and 7 of 15 phages carry the sak toxin gene. The phage group \#3 contained eight phages and none of the phages carry the sak gene. Although the combinations of the toxin genes in the groups were similar, there are some differences. For example, only three of the samples in group \#5 carried the $s c n$ toxin gene. Since all 15 RFLP phage profiles look the same, we expected to see the same combinations of toxin genes. This unexpected finding might be related to bacteria which may contain more than one phage in their genome. Similarly, it was shown that eight different families are prevalent in $S$. aureus and $\varphi 3$ bacteriophage is the most prevalent bacteriophage [18]. In addition, it was shown that $\varphi 3$ bacteriophage carries different combinations of the virulence genes $[18,19]$. Although our approach does not allow drawing conclusions whether the found virulence genes are present on a single phage or are distributed on different phages, we may conclude that group \#5 contains the same prophage or prophages. In addition, a series of discrete 15-20 kb chromosomal elements that encode SEs and reside at specific locations were identified [8]. These are referred to as staphylococcal pathogenicity islands (SaPIs). It was shown that some SaPIs are mobilized by staphylococcal transducing phages [20]. These SaPIs were detected together with the phage DNA on the agarose gel [8]. This may particularly explain the differences of toxin genes' profiles and discrepancy in RFLP.

The gene encoding SCIN (scn) was shown as to be a part of IEC [21]. Seven IEC variants have been identified [22]. All IEC variants carry scn and a different combination of sea, sak, and chp. The scn and chp genes are found in 6/7 and 
3/7 sequenced $S$. aureus strains, respectively [16]. Analyses of these sequenced genomes showed that both the scn and chp are carried by $\beta$-hemolysin (hlb)converting bacteriophages ( $\beta \mathrm{C}-\varphi \mathrm{s})$ [16]. In $90 \%$ of strains from a genetically diverse clinical $S$. aureus strain collection, a $\beta C-\varphi$ was found that carries one of the seven IEC variants. It is also indicated that $\beta C-\varphi s$ contain common sequence such as $s c n$ in their genome and $\beta C$ containing phages might be different from each other. In this study, it was found that only 13 of the 43 phages contained scn in their genome and 16 of the 43 phages carry chp. Therefore, it may be concluded that CHIPS are not found only in the $\beta C-\varphi s$ and combination with the SCIN in IEC variants.

SAK is a bacterial plasminogen activator [21, 23]. Different studies observed that staphylococci coming from different samples contain up to $80 \%$ sak gene in their chromosomes [23]. It is also observed that there is a clear correlation between producing sak and belonging of a strain to a bacteriophage group [15, 23]. In addition, these strains do not constitute a homogenous group, and they belong to different phage types [23]. The results of our study showed that $55 \%$ of the phages contained the sak gene. Similar to the previous study, we also observed that different phage types may contain the sak gene. Although we do not know the characteristics of group \#3, which contained seven phages, none of the phages contained the sak gene. This may conclude that the sak gene is carried with different combinations of gene clusters in addition to IEC in the different phages.

PVL, a pore-forming cytotoxin selectively disrupts leukocyte membranes, leading to increased virulence. In the late 1990s, the first PVL-positive MRSA isolates were observed and such strains have spread globally in recent years [24]. The presence of $l u k F-P v$ shows diversity depending on different factors. For example, a higher proportion of $S$. aureus strains (both MSSA and MRSA strains) that were derived from skin and soft tissue infection contain the $l u k F-P V$ gene compared to the $S$. aureus strains isolated from blood [25]. In addition to that, more CA-MRSA genotypes contain the lukSF-PV gene compared to the HA-MRSA [26]. It was also shown that $l u k F-P v$ carrying phages contain fewer enterotoxin genes than strains without $l u k F-P V[25,26]$. In this study, none of the 43 phages contain the $l u k F-P V$ gen. This may particularly be explained by the number of the CA-MRSA used in the study. Although 12 CA-MRSA were screened, only eight of them contain the phages. In addition to that, in our results, $96 \%$ of the phages contained more than one toxin in their genome.

The eta gene encoding ETA is previously believed to be located on the chromosome of $S$. aureus, whereas the gene for ETB is located on a large plasmid [27-30]. Yoshizawa et al. [31] described, for the first time, a temperate phage that carried the structural gene for ETA from an ETA-producing strain of $S$. aureus. Yamaguchi et al. [32] also isolated a phage ( $\varphi$ ETA) that encodes an ETA from $S$. aureus, isolated from a human impetigo patient, and determined the complete 
nucleotide sequence of the $\varphi$ ETA genome. Recently, we isolated an eta gene carrying phage obtained from MRSA strain isolated from the blood of the patient without any skin lesion [33]. Both in the previous study and this study, we showed that the MRSA $\varphi$ ETA genome was different from the genomes of the other phages. In addition to differences of MRSA $\varphi$ ETA, we previously showed that ETA-carrying MRSA isolate is also quite different from the other MRSA isolates examined in the study. In addition to this, toxin genes' profile is unique compared to the other phages' toxin profiles.

Enterotoxin gene, seq, encodes pyrogenic toxin superantigens that lack emetic activity in monkeys, a defining biological feature of classical staphylococcal enterotoxins [34]. Molecular analyses indicate that early MSSA and MRSA strains may acquire pathogenicity island (SaPI) 3, which contains the genes for three potent enterotoxins, seb, sek, and seq [35]. The sek and seq were adjacent genes in the $S$. aureus, separated by only 15 nucleotides, and also encoded similar predicted amino acid sequences [35]. Similarly, we found that $27 \mathrm{seq}$ toxin genes containing phages also carry the sek gene.

The staphylococcal enterotoxin-like toxin type P (SEIP) is a novel SErelated toxin gene. It was identified as sep after the full genome sequencing of the S. aureus N315 strain [36]. A recent study showed that SEIP found only 3 of the 481 strains of $S$. aureus carried with prophages [37]. In this study, we found that neither of the phage carries selp gene. Therefore, selp carriage is relatively low compared to the other superantigens. It may be concluded that specific clusters or phages in restricted $S$. aureus strains carry selp.

Herein, we analyzed the phages obtained only from MRSAs. A study showed that there are superantigenic toxin genotypes in both MRSA, and MSSA isolates from clinical specimens. Of the 118 MRSA isolates, all strains were diagnosed as positive for superantigenic toxin genes. In contrast to the MRSA isolates, 34 isolates $(24.3 \%)$ of the 140 MSSA isolates were diagnosed as negative for superantigenic toxin genes [11]. Therefore, MRSAs have the tendency for carrying toxin genes more than MSSAs.

In conclusion, although only 10 virulence factors were searched, this study indicates that prophages encode a large proportion of MRSA virulence factors and provide the pathogen with a large variety of toxins. Although our approach does not allow drawing conclusions whether the found virulence genes are present on a single phage or are distributed on different phages, it may indicate that toxin genes are carried in the different phages possibly with different gene clusters. Though the techniques used by us may not have allowed the identification of all the toxin genes we searched for and some of the genes detected could have been located on genetic islands (as indicated above), our findings clearly demonstrate the relevant differences between the toxin genes' content of CA-MRSA and HA-MRSA 
isolates and between various groups of phages. Obviously, further characterization of the whole genome of strains and phages will give more information for noninducible phages and SaPIs.

\section{Acknowledgement}

This work was supported by The Scientific \& Technological Research Council of Turkey (TUBITAK) with project number: SBAG-3234 (105S427). No competing financial interests exist.

\section{Conflict of Interest}

There is no conflict of interest.

\section{References}

1. Larkin, E. A., Carman, R. J., Krakauer, T., Stiles, B. G.: Staphylococcus aureus: The toxic presence of a pathogen extraordinaire. Curr Med Chem 16, 4003-4019 (2009).

2. DeLeo, F. R., Chambers, H. F.: Reemergence of antibiotic-resistant Staphylococcus aureus in the genomics era. J Clin Invest 119, 2464-2474 (2009).

3. Woodford, N., Livermore, D. M.: Infections caused by Gram-positive bacteria: A review of the global challenge. J Infect 59, S4-S16 (2009).

4. Hawkey, P. M., Jones, A. M.: The changing epidemiology of resistance. J Antimicrob Chemother 64, i3-i10 (2009).

5. Deghorain, M., Van Melderen, L.: The Staphylococci phages family: An overview. Viruses 4, 3316-3335 (2012).

6. Pinchuk, I. V., Beswick, E. J., Reyes, V. E.: Staphylococcal enterotoxins. Toxins 2, $2177-$ 2197 (2010).

7. Xu, S. X., McCormick, J. K.: Staphylococcal superantigens in colonization and disease. Front Cell Infect Microbiol 2, 52 (2012).

8. Novick, R. P.: Mobile genetic elements and bacterial toxinoses: The superantigen-encoding pathogenicity islands of Staphylococcus aureus. Plasmid 49, 93-105 (2003).

9. Ortega, E., Abriouel, H., Lucas, R., Galvez, A.: Multiple roles of Staphylococcus aureus enterotoxins: Pathogenicity, superantigenic activity, and correlation to antibiotic resistance. Toxins 2, 2117-2131 (2010).

10. Goerke, C., Pantucek, R., Holtfreter, S., Schulte, B., Zink, M., Grumann, D., Broker, B. M., Doskar, J., Wolz, C.: Diversity of prophages in dominant Staphylococcus aureus clonal lineages. J Bacteriol 191, 3462-3468 (2009).

11. Hu, D. L., Omoe, K., Inoue, F., Kasai, T., Yasujima, M., Shinagawa, K., Nakane, A.: Comparative prevalence of superantigenic toxin genes in methicillin-resistant and methicillinsusceptible Staphylococcus aureus isolates. J Med Microbiol 57, 1106-1112 (2008). 
12. Tan, T. Y.: A comparison of PCR detection of mecA with two standard methods of oxacillin disk susceptibility testing for coagulase-negative Staphylococci. J Med Microbiol 51, 83-85 (2002).

13. Kaneko, J., Kimura, T., Kawakami, Y., Tomita, T., Kamio, Y.: Panton-valentine leukocidin genes in a phage-like particle isolated from mitomycin C-treated Staphylococcus aureus V8 (ATCC 49775). Biosci Biotechnol Biochem 61, 1960-1962 (1997).

14. Sinzger, C., Knapp, J., Schmidt, K., Kahl, M., Jahn, G.: A simple and rapid method for preparation of viral DNA from cell associated cytomegalovirus. J Virol Methods 81, 115122 (1999).

15. Xia, G., Wolz, C.: Phages of Staphylococcus aureus and their impact on host evolution. Infect Genet Evol 21, 593-601 (2013).

16. van Wamel, W. J., Rooijakkers, S. H., Ruyken, M., van Kessel, K. P., van Strijp, J. A.: The innate immune modulators staphylococcal complement inhibitor and chemotaxis inhibitory protein of Staphylococcus aureus are located on $\beta$-hemolysin-converting bacteriophages. J Bacteriol 188, 1310-1315 (2006).

17. Normanno, G., Firinu, A., Virgilio, S., Mula, G., Dambrosio, A., Poggiu, A., Decastelli, L., Mioni, R., Scuota, S., Bolzoni, G., Di Giannatale, E., Salinetti, A. P., La Salandra, G., Bartoli, M., Zuccon, F., Pirino, T., Sias, S., Parisi, A., Quaglia, N. C., Celano, G. V.: Coagulase-positive Staphylococci and Staphylococcus aureus in food products marketed in Italy. Int J Food Microbiol 98, 73-79 (2005).

18. Lindsay, J. A., Holden, M. T.: Understanding the rise of the superbug: Investigation of the evolution and genomic variation of Staphylococcus aureus. Funct Integr Genomics 6, 186201 (2006).

19. McCarthy, A. J., Witney, A. A., Lindsay, J. A.: Staphylococcus aureus temperate bacteriophage: Carriage and horizontal gene transfer is lineage associated. Front Cell Infect Microbiol 2, 6 (2012).

20. Lindsay, J. A., Ruzin, A., Ross, H. F., Kurepina, N., Novick, R. P.: The gene for toxic shock toxin is carried by a family of mobile pathogenicity islands in Staphylococcus aureus. Mol Microbiol 29, 527-543 (1998).

21. Verkaik, N. J., Benard, M., Boelens, H. A., de Vogel, C. P., Nouwen, J. L., Verbrugh, H. A., Melles, D. C., van Belkum, A., van Wamel, W. J.: Immune evasion cluster-positive bacteriophages are highly prevalent among human Staphylococcus aureus strains, but they are not essential in the first stages of nasal colonization. Clin Microbiol Infect 17, 343-348 (2011).

22. Rooijakkers, S. H., Ruyken, M., Roos, A., Daha, M. R., Presanis, J. S., Sim, R. B., van Wamel, W. J., van Kessel, K. P., van Strijp, J. A.: Immune evasion by a staphylococcal complement inhibitor that acts on C3 convertases. Nat Immunol 6, 920-927 (2005).

23. Piechowicz, L., Galin'ski, J., Garbacz, K., Haras, K.: Bacteriophage analysis of staphylokinase-negative Staphylococcus aureus strains isolated from people. J Basic Microbiol 50, 557-561 (2010).

24. Monecke, S., Slickers, P., Ellington, M. J., Kearns, A. M., Ehricht, R.: High diversity of Panton-Valentine leukocidin-positive, methicillin-susceptible isolates of Staphylococcus aureus and implications for the evolution of community-associated methicillin-resistant S. aureus. Clin Microbiol Infect 13, 1157-1164 (2007).

25. Kaltsas, A., Guh, A., Mediavilla, J. R., Varshney, A. K., Robiou, N., Gialanellia, P., Henry, M., Levi, M. H., Fries, B. C.: Frequency of panton-valentine leukocidin- 
producing methicillin-sensitive Staphylococcus strains in patients with complicated skin and soft tissue infection in Bronx, New York. J Clin Microbiol 49, 2992-2995 (2011).

26. Varshney, A. K., Martinez, L. R., Hamilton, S. M., Bryant, A. E., Levi, M. H., Gialanella, P., Stevens, D. L., Fries, B. C.: Augmented production of Panton-Valentine leukocidin toxin in methicillin-resistant and methicillin-susceptible Staphylococcus aureus is associated with worse outcome in a murine skin infection model. J Infect Dis 201, 92-96 (2010).

27. Keyhani, M., Rogolsky, M., Wiley, B. B., Glasgow, L. A.: Chromosomal synthesis of staphylococcal exfoliative toxin. Infect Immun 12, 193-197 (1975).

28. Warren, R., Rogolsky, M., Wiley, B. B., Glasgow, L. A.: Isolation of extrachromosomal deoxyribonucleic acid for exfoliative toxin production from phage group II Staphylococcus aureus. J Bacteriol 122, 99-105 (1975).

29. O'Toole, P. W., Foster, T. J.: Molecular cloning and expression of the epidermolytic toxin A gene of Staphylococcus aureus. Microb Pathog 1, 583-594 (1986).

30. Lee, C. Y., Schmidt, J. J., Johnson-Winegar, A. D., Spero, L., Iandolo, J. J.: Sequence determination and comparison of the exfoliative toxin A and toxin B genes from Staphylococcus aureus. J Bacteriol 169, 3904-3909 (1987).

31. Yoshizawa, Y., Sakurada, J., Sakurai, S., Machida, K., Kondo, I., Masuda, S.: An exfoliative toxin A-converting phage isolated from Staphylococcus aureus strain ZM. Microbiol Immun 44, 189-191 (2000).

32. Yamaguchi, T., Hayashi, T., Takami, H., Nakasone, K., Ohnishi, M., Nakayama, K., Yamada, S., Komatsuzawa, H., Sugai, M.: Phage conversion of exfoliative toxin A production in Staphylococcus aureus. Mol Microbiol 38, 694-705 (2000).

33. Sahin, F., Karasartova, D., Ozsan, T. M., Kiyan, M., Karahan, C. Z., Tekeli, A.: Identification of methicillin-resistant Staphylococcus aureus carrying an exfoliative toxin A gene encoding phage isolated from a hospitalized patient in Turkey. Can J Microbiol 59, 260-265 (2013).

34. Orwin, P. M., Leung, D. Y., Tripp, T. J., Bohach, G. A., Earhart, C. A., Ohlendorf, D. H., Schlievert, P. M.: Characterization of a novel staphylococcal enterotoxin-like superantigen, a member of the group V subfamily of pyrogenic toxins. Biochemistry 41, 14033-14040 (2002).

35. Yarwood, J. M., McCormick, J. K., Paustian, M. L., Orwin, P. M., Kapur, V., Schlievert, P. M.: Characterization and expression analysis of Staphylococcus aureus pathogenicity island 3. Implications for the evolution of staphylococcal pathogenicity islands. J Biol Chem 277, 13138-13147 (2002).

36. Omoe, K., Imanishi, K., Hu, D. L., Kato, H., Fugane, Y., Abe, Y., Hamaoka, S., Watanabe, Y., Nakane, A., Uchiyama, T., Shinagawa, K.: Characterization of novel staphylococcal enterotoxin-like toxin type P. Infect Immun 73, 5540-5546 (2005).

37. Bianchi, D. M., Gallina, S., Bellio, A., Chiesa, F., Civera, T., Decastelli, L.: Enterotoxin gene profiles of Staphylococcus aureus isolated from milk and dairy products in Italy. Lett Appl Microbiol 58, 190-196 (2013). 